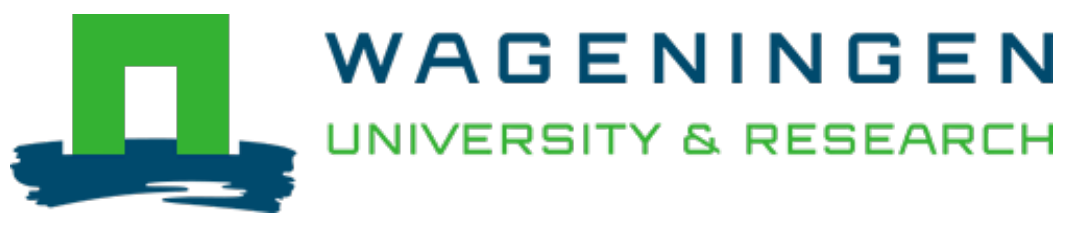

\title{
Dry milling and accelerated fermentation of maize for industrial production of kenkey, a Ghanaian cereal food.
}

Journal of Cereal Science

Nche, P.F.; Odamtten, G.T.; Nout, M.J.R.; Rombouts, F.M.

https://doi.org/10.1006/jcrs.1994.1069

This publication is made publicly available in the institutional repository of Wageningen University and Research, under the terms of article $25 \mathrm{fa}$ of the Dutch Copyright Act, also known as the Amendment Taverne. This has been done with explicit consent by the author.

Article 25 fa states that the author of a short scientific work funded either wholly or partially by Dutch public funds is entitled to make that work publicly available for no consideration following a reasonable period of time after the work was first published, provided that clear reference is made to the source of the first publication of the work.

This publication is distributed under The Association of Universities in the Netherlands (VSNU) 'Article $25 \mathrm{fa}$ implementation' project. In this project research outputs of researchers employed by Dutch Universities that comply with the legal requirements of Article $25 \mathrm{fa}$ of the Dutch Copyright Act are distributed online and free of cost or other barriers in institutional repositories. Research outputs are distributed six months after their first online publication in the original published version and with proper attribution to the source of the original publication.

You are permitted to download and use the publication for personal purposes. All rights remain with the author(s) and / or copyright owner(s) of this work. Any use of the publication or parts of it other than authorised under article $25 \mathrm{fa}$ of the Dutch Copyright act is prohibited. Wageningen University \& Research and the author(s) of this publication shall not be held responsible or liable for any damages resulting from your (re)use of this publication.

For questions regarding the public availability of this publication please contact openscience.library@wur.nl 


\title{
Dry Milling and Accelerated Fermentation of Maize for Industrial Production of Kenkey, a Ghanaian Cereal Food
}

\author{
P. F. Nche*, G. T. Odamttent, M. J. R. Nout* $\ddagger$ and F. M. Rombouts* \\ * Wageningen Agricultural University, Department of Food Science, Bomenweg 2, $6703 \mathrm{HD}$ \\ Wageningen, The Netherlands and TUniversity of Ghana, Department of Botany, PO Box 55, Legon/ \\ Accra, Ghana \\ Received 15 December 1993
}

\begin{abstract}
The dry milling of maize and accelerated fermentation of dough for kenkey production were studied as part of a wider investigation into the possibility of industrial production of a dehydrated kenkey flour. Dough containing an enrichment of lactic acid bacteria was used successfully to achieve, within 24-h incubation at $30^{\circ} \mathrm{C}$, the required level of acidification of dry-milled maize flour to obtain kenkey dough. Cabinet and drum drying were used to prepare debydrated kenkey flour and pre-gelatinised aflata, respectively. Drum-drying was an effective method for the preparation of pre-gelatinised aflata, but it resulted in a $34 \%$ reduction in the titratable acidity (TA) of the fermented dough. Cabinet drying, on the other hand, had a less drastic effect on the TA of fermented dough, suggesting the possible use of a mixture of drum-dried aflata and uncooked cabinet-dried flour for convenient preparation of kenkey at the household level. Dry-milled maize flours had pasting and set-back viscosities that were inferior to those of the traditionally prepared doughs, and consequently they were unsuitable for the production of pre-gelatinised aflatas. Pre-getalinised aflata from unfermented dry-milled flours resulted in a crumbly and friable kenkey product. It was concluded, therefore, that, although dry-milling of maize and accelerated fermentation of dough could drastically reduce kenkey production time, from about 6 days to within $24 \mathrm{~h}$, omission of the soaking step practised traditionally results in a product with inferior textural quality.
\end{abstract}

\section{INTRODUCTION}

Kenkey is a popular traditional, fermented maize product, still prepared commercially on a small artisan scale in Ghana. The traditional kenkey process has been described earlier ${ }^{1-3}$. In this process, maize is cleaned and steeped in excess water for 2 days, followed by milling. The meal obtained

ABBREVIATIONS USED: $\mathrm{TA}=$ titratable acidity; $\mathrm{LAB}=$ lactic acid bacteria; $\mathrm{TF}=$ traditionally soaked and fermented; TUF $=$ traditionally soaked but unfermented; DUF $=$ dry milled and unfermented; DAF $=$ dry milled and accelerated fermented; $\mathrm{BU}=$ Brabender Amylograph viscosity units.

+ To whom correspondence should be addressed. is made into a dough by adding water $(1: 3 ; \mathrm{v} / \mathrm{w})$ and allowed to ferment naturally. The period for natural dough fermentation and souring varies from 2-4 days, but it has been shown that 2 days at $30^{\circ} \mathrm{C}$ are sufficient to obtain the desired degree of souring ${ }^{3}$. The fermented dough is divided into two equal portions, one of which is slurried and stir-cooked to gelatinisation, giving rise to a sticky paste called the aflata, having a glutinous consistency ${ }^{1}$. There is some dispute over which intermediate product should be called the aflata, but most reports and most indigenous kenkey consumers agree with the description by Muller ${ }^{l}$, which we have also adopted in this paper. The aflata is usually mixed in equal proportion with the uncooked portion to produce a dumpling from which balls of appropriate size $(\approx 300-500 \mathrm{~g})$ are 
shaped, wrapped in maize sheaths (ga kenkey) or banana leaves (fanti kenkey) and cooked for 1-3 h, depending on the size, to give kenkey.

In the traditional process, the soaking step not only softens the grains, thereby facilitating smooth milling, but also stimulates enzyme activity leading to amylolysis and proteolysis, which contribute to the desired physical, chemical and organoleptic properties characteristic of kenkey ${ }^{4}$.

The technical feasibility of preparing a dehydrated kenkey flour for kenkey manufacture at the household level or in a small-scale industry has not been explored to date. The total time taken to prepare kenkey the traditional way, from steeping to cooking, can be as much as 6 days. To adapt such a process to an industrial scale would require, amongst other technical adaptations, a reduction in production time. This means, therefore, that the various steps in the whole process have to be looked at and modified, where necessary, to suit an industrial-scale process, without compromising the quality of the final product significantly. One way of reducing production time is to mill the dry grains and to omit the soaking step. Dough from this can then be fermented rapidly by using a starter dough containing an enrichment of lactic acid bacteria (LAB).

Our objectives in this study were to investigate the technological feasibility of producing kenkey from dry-milled maize. This involved an investigation of the effects of dry-milling, compared with soaking before milling, on the gelatinisation of maize flour for aflata production and on the subsequent physical characteristics of the final product. Also, the use of starter dough to accelerate fermentation was investigated.

\section{EXPERIMENTAL}

Maize (Zea mays L. cv. obaatanba) was supplied by the Council for Scientific and Industrial Research (CSIR), Crops Research Institute, Kwadaso, Ghana. Grains were milled using a hammer mill (Fritsch Pulverisette, Type 14.702, Marius Instruments, Utrecht, The Netherlands) with a fine rotor. Rotor speed was set on 2 and grains were milled to pass through a 4 -mm sieve.

\section{Microbiological analyses}

Sample preparation and enumeration of lactic acid bacteria (LAB), moulds and yeasts and Enterobacteriaceae were as described by Nout et al. ${ }^{5}$.

\section{$\mathrm{pH}$ and acidity}

A pH meter (Electrofact, Sweden) with a Schott N61 electrode was used to measure $\mathrm{pH}$ of fermenting dough. Distilled water $(90 \mathrm{ml})$ was added to the sample $(10 \mathrm{~g})$ and mixed in a blender (Stomacher 400 Type BA 7021, Seward Medical, London, U.K.) before recording the $\mathrm{pH}$. Titratable acidity was determined according to Nout $e t a l .{ }^{6}$.

\section{Pasting viscosity}

A Brabender Visco-Amylograph (Brabender, Duisberg, Germany) was used to compare the hot and cold paste viscosities of traditionally fermented (TF) and unfermented (TUF) maize doughs as well as dry-milled, unfermented (DUF) and accelerated (starter) fermented (DAF) maize doughs. Samples were tested at $9 \%(\mathrm{w} / \mathrm{w})$ dry solids basis. The slurry in the Visco-Amylograph bowl was heated from $50^{\circ} \mathrm{C}$ at a rate of $1.5^{\circ} \mathrm{C} / \mathrm{min}$ to a maximum temperature of $95^{\circ} \mathrm{C}$. The temperature was maintained at this maximum for $30 \mathrm{~min}$ before cooling at a rate of $1.5^{\circ} \mathrm{C} / \mathrm{min}$ back to $50^{\circ} \mathrm{C}$. A $250-\mathrm{cmg}$ cartridge was used and the bowl speed was set at $75 \mathrm{rev} / \mathrm{min}$. Viscosity was recorded in Brabender Units.

\section{Colour determination}

Colour parameters $L, a$ and $b$, representing luminosity (brightness), redness and yellowness, respectively, were measured using a DR Lange Tricolor LFM 3 Colorimeter (Hunterlab, 9529, Lee Highway, Fairfax, Virginia), calibrated with a standard white tile $(L=88.20, a=-0.96, b=$ $-1 \cdot 69)$. Two measurements were made of both surfaces of each sample.

\section{Textural measurements}

Fracture stress was measured with an Overload Dynamics, Instron-type instrument (Marius Instruments, Utrecht, The Netherlands), with two plates between which samples of standard cylindrical dimensions (length, $3 \mathrm{~cm}$; diameter, $2 \mathrm{~cm}$ ) were placed vertically and compressed at constant speed $(50 \mathrm{~mm} / \mathrm{min})$ until fracture point. Fracture stress was calculated according to Van Vliet ${ }^{7}$.

\section{Accelerated natural fermentation}

A LAB-enriched starter dough was prepared by 'back-slopping' ${ }^{6}$. Initially, a previously $24-h$ nat- 
urally fermented dough was used to inoculate (at the $10 \%, w / w$, level) fresh dough for a further $24-\mathrm{h}$ fermentation at $30^{\circ} \mathrm{C}$. This was repeated until a stable culture, as indicated by a stable $\mathrm{pH}$, TA and microbial count, was obtained (Fig. 3). This was then used as a starter to accelerate the fermentation of fresh dry-milled maize dough. Inoculated dough was incubated at $30^{\circ} \mathrm{C}$ for $24 \mathrm{~h}$ to obtain an accelerated fermented dough (Fig. 2) that was then used for laboratory preparation of kenkey as described earlier ${ }^{3}$.

\section{Drying}

Two types of drying methods, viz. cabinet- and drum-drying, were used. For cabinet-drying, traditionally fermented maize dough was spread on trays and placed in an electrically heated circulating air cabinet drier maintained at $60^{\circ} \mathrm{C}$. Drying was done over a period of $3 \mathrm{~h}$, during which samples were taken out hourly for moisture, $\mathrm{pH}$ and titratable acidity measurements.

For drum-drying, three differently treated doughs were used. These were traditionally fermented dough (TF), traditionally soaked but unfermented maize dough (TUF) and dry-milled unfermented maize dough (DUF). During drum drying, a $20 \%(w / v)$ dough slurry (in tap water) was applied onto the pre-heated $\left(140^{\circ} \mathrm{C}\right)$ rotating $(1.5 \mathrm{rev} / \mathrm{min})$ drum of the drum drier (NV Goudsche Machinefabriek, Waddinxveen, The Netherlands). A film thickness of $0.2 \mathrm{~mm}$ was maintained.

\section{Aflata and kenkey processing}

Figures 1 and 2 summarise the schemes used for producing kenkey. Drum-dried dough was reconstituted by adding tap water $(1: 3 ; \mathrm{w} / \mathrm{v})$. This gave a gluey paste, the aflata, which was then mixed, in equal proportion, with cabinet-dried, traditionally fermented dough to produce a dumpling, from which portions (ca. $300 \mathrm{~g}$ ) were shaped into cylinders (25-30 $\mathrm{mm}$ diameter; $10 \mathrm{~cm}$ length) and wrapped, first in polyethylene sheaths and then aluminium foil ${ }^{3}$. These were then boiled for i h to give kenkey [Fig. I (a)]. Aflatas from wetand dry-milled unfermented drum-dried maize doughs were also mixed, in equal proportions, with cabinet-dried traditionally fermented dough to produce kenkey [Fig. 1 (b) and Fig. 2 (c), respectively]. Kenkey was also produced from both traditionally ${ }^{3}$ (Fig. 1) and accelerated [Fig. 2 (d)] fermented doughs.

\section{Sensory evaluation}

The appearance, texture, smell and taste of all experimental kenkey products were compared with laboratory-made 'traditional' kenkey by a fourmember panel consisting of one Ghanaian familiar with kenkey and three untrained panellists.

Sensory evaluation of samples of kenkey was carried out in Ghana by a 10 -member trained taste panel, in triplicate, on 3 consecutive days. The samples were judged on the basis of the following attributes and properties: appearance (usual kenkey colour, acceptable kenkey colour, uniform mix), texture (breaks easily, crumbliness, softness, hardness, mouldability, stickiness to fingers and palm), smell (strong, mild, no smell, kenkey) and taste (pleasant, sour, chewiness, sticks in throat, pleasant after-taste).

\section{RESULTS}

The lactic acid bacteria population of naturally fermenting, soaked maize dough increased by about $2 \log$ cycles in 2 days, after which it stabilised (Table I). The mould and yeast counts remained very low $\left(\log _{10}<2.7 \mathrm{cfu} / \mathrm{g}\right)$ throughout incubation. The Enterobacteriaceae count, on the other hand, fell from an initial high level $\left(\log _{10} 6.1 \mathrm{cfu} / \mathrm{g}\right)$ on day 0 to $\log _{10} 2 \cdot 7 \mathrm{cfu} / \mathrm{g}$ within $24 \mathrm{~h}$. Within the same period of time, the $\mathrm{pH}$ of the fermenting dough decreased from an initial 5.24 to 3.96 , and thereafter remained constant (Table I). This decrease in $\mathrm{pH}$ was accompanied by an increase in titratable acidity (Table I) to a final value of $0.92 \%$ (expressed as $w / w$ lactic acid, wet basis).

After three 'back-slopping' cycles at $30^{\circ} \mathrm{C}$, the measured parameters of the starter dough remained relatively constant (Fig. 3), suggesting the establishment of a stable microflora. This was used successfully to obtain an accelerated acidification of fresh dough. Within $24 \mathrm{~h}$, the $\mathrm{pH}$ of the inoculated dough dropped from 5.65 to 3.79 , and a titratable acidity value of $1 \cdot 24 \%$ (wet-weight basis) was significantly higher than was obtained after 3 days for traditionally fermented dough.

Drying the traditionally fermented maize dough at $60^{\circ} \mathrm{C}$ for $3 \mathrm{~h}$ in a cabinet drier reduced the moisture content from $54-10 \%$ without significantly affecting its $\mathrm{pH}$ (Table II). Only a mar- 


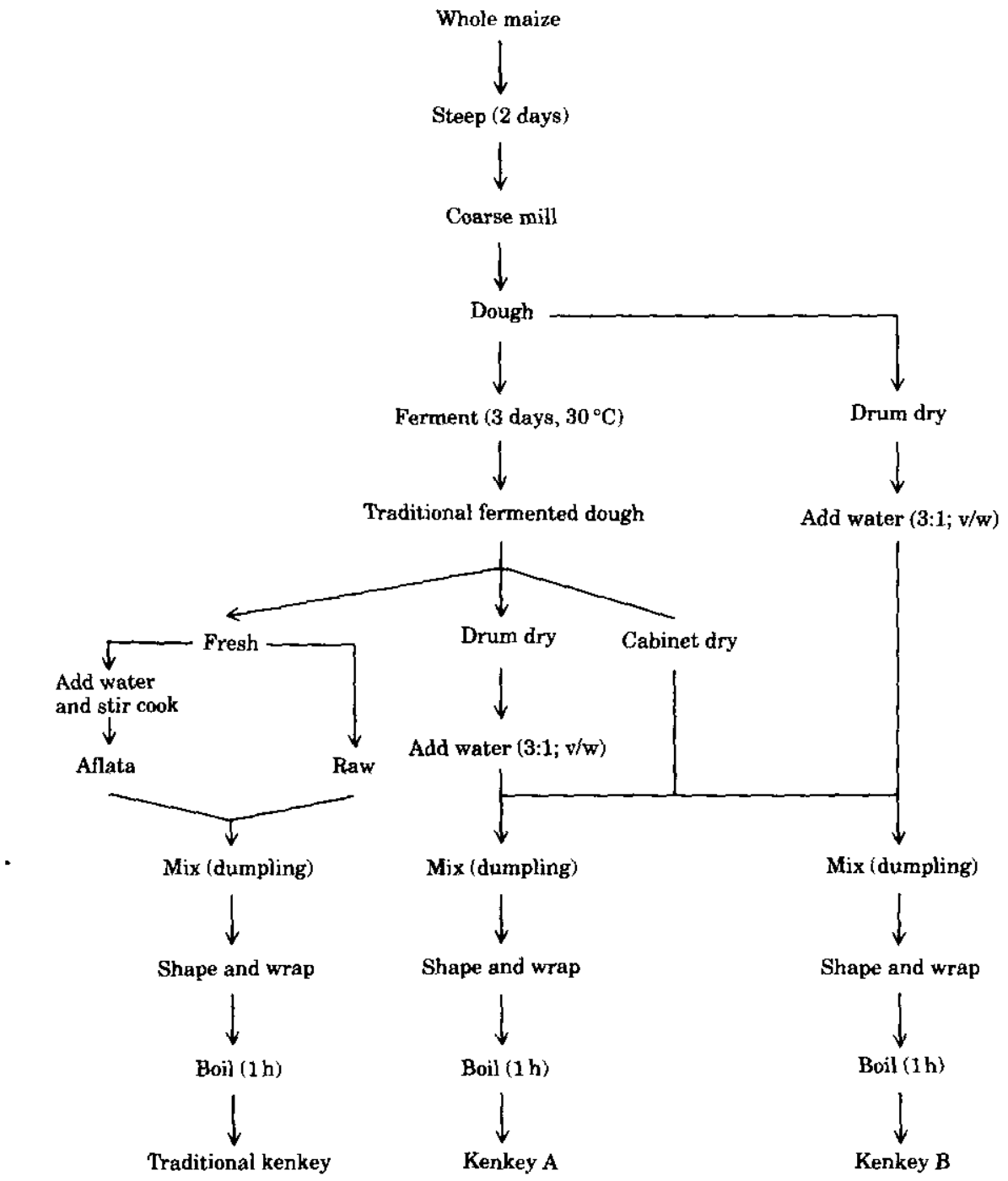

Figure 1 Scheme for the production of kenkey from traditionally fermented maize dough.

ginal decrease in titratable acidity from $2 \cdot 87 \%$ to $2.49 \%$ (dry-weight basis) was observed. Drum drying resulted in a significant $(P<0 \cdot 05)$ reduction in the TA of freshly fermented dough, however, from $2 \cdot 87 \%$ to $1.90 \%$ ( $\mathrm{w} / \mathrm{w}$ as lactic acid).

The pasting viscosities of standard slurries of the differently prepared maize doughs are shown in Fig. 4. Traditionally fermented maize dough (TF) gave the highest peak viscosity of 950 Brabender Units (BU) with the highest set-back value. The corresponding unfermented maize dough (TUF) had lower peak and set-back viscosity values (Fig. 4). Both these doughs had significantly higher setback viscosities than dry-milled accelerated fermented (DAF) and dry-milled unfermented (DUF) doughs.
Table III shows that there was no significant difference in colour between traditionally made kenkeys and those made by the accelerated process. There was some loss in luminosity of dough when processed into kenkey, however. The luminosity $(L)$ values for kenkey were comparable with values obtained earlier ${ }^{3}$ for traditional kenkey.

Table IV shows the fracture stress, a textural measure of the hardness of the product. There was no significant difference $(P<0.05)$ in fracture stress values for traditional kenkey and kenkey D. Both these kenkeys had higher, though not significant, fracture stress values than kenkeys A and $B$. Only kenkey $\mathrm{C}$ had a significantly lower fracture stress value.

Sensory assessment at the laboratory level re- 


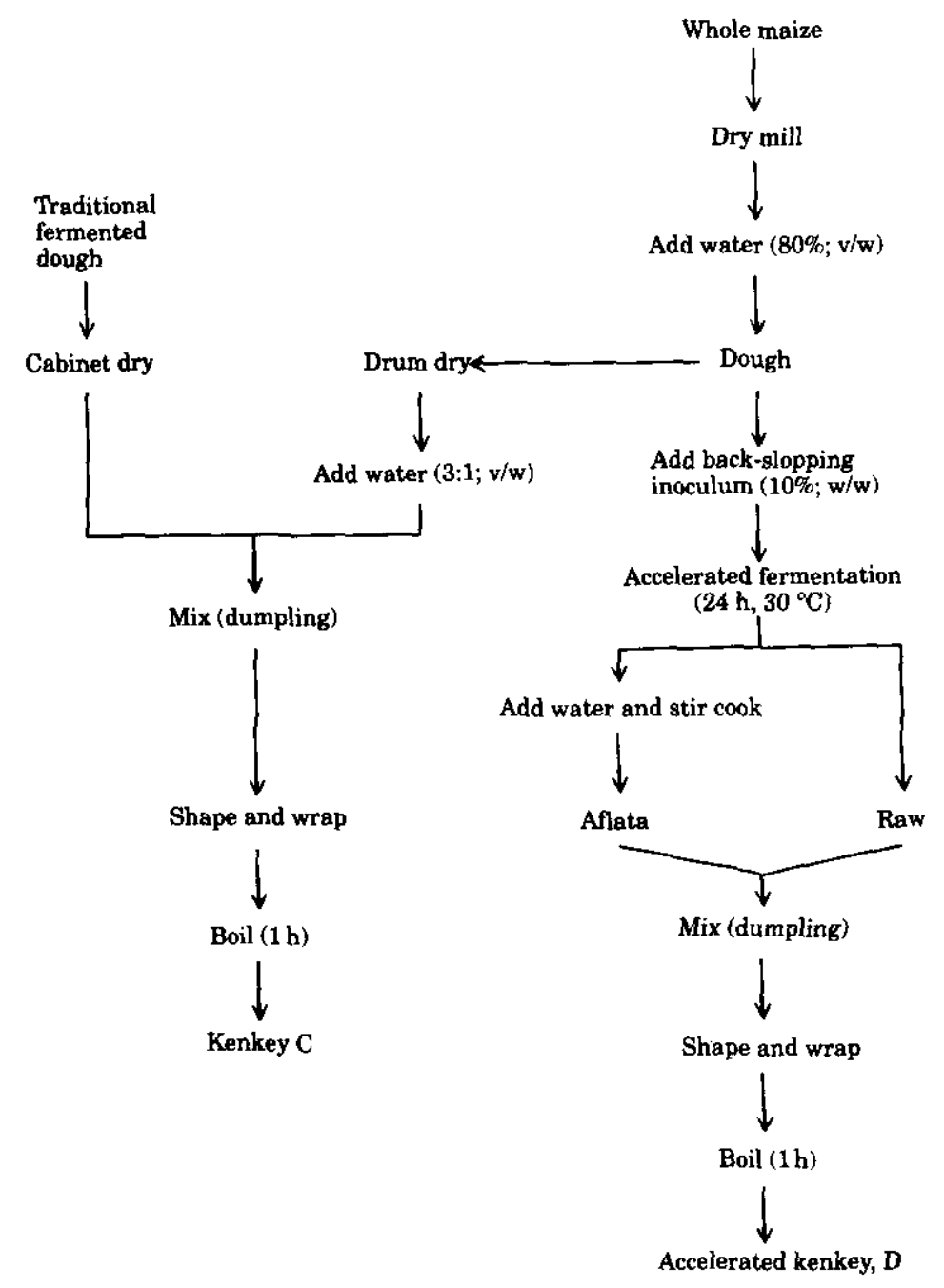

Figure 2 Scheme for the production of kenkey from dry-milled maize flour.

vealed that, compared with Jaboratory-made 'traditional' kenkey, kenkey products B, C and D were of unsatisfactory texture, taste and smell. On the other hand, kenkey A got promising assessments; this product was selected for sensory evaluation by a local Ghanaian panel.
During sensory evaluation in Ghana, the following samples were compared: (1) kenkey prepared by reconstituting and cooking of dry kenkey mix [Fig. 1 (a)]; and (2), local samples of kenkey bought from the same vendor each day. Both types 1 and 2 were perceived as normal ga kenkey of

Table I Fermentation parameters of wet-milled maize dough

\begin{tabular}{lccccc}
\hline $\begin{array}{l}\text { Time } \\
\text { (days) }\end{array}$ & $\mathrm{pH}$ & $\begin{array}{c}\text { Titratable } \\
\text { acidity }(\%)^{\mathrm{a}}\end{array}$ & $\mathrm{LAB}^{\mathrm{b}}$ & Yeasts $^{\mathrm{b}}$ & Enterobacteriaceat $^{\mathrm{b}}$ \\
\hline 0 & $5 \cdot 24$ & $0 \cdot 37$ & $6 \cdot 9$ & $<2 \cdot 7$ & $6 \cdot 1$ \\
1 & 3.96 & 0.83 & $7 \cdot 4$ & $<2 \cdot 7$ & $<2 \cdot 7$ \\
2 & 3.94 & 0.92 & $8 \cdot 8$ & $<2 \cdot 7$ & $<2 \cdot 7$ \\
3 & 3.95 & 0.92 & $8 \cdot 5$ & $<2 \cdot 7$ & $<2 \cdot 7$ \\
\hline
\end{tabular}

${ }^{a}$ Expressed as lactic acid (w/w).

${ }^{b} \log _{10} \mathrm{cfu} / \mathrm{g}$. 


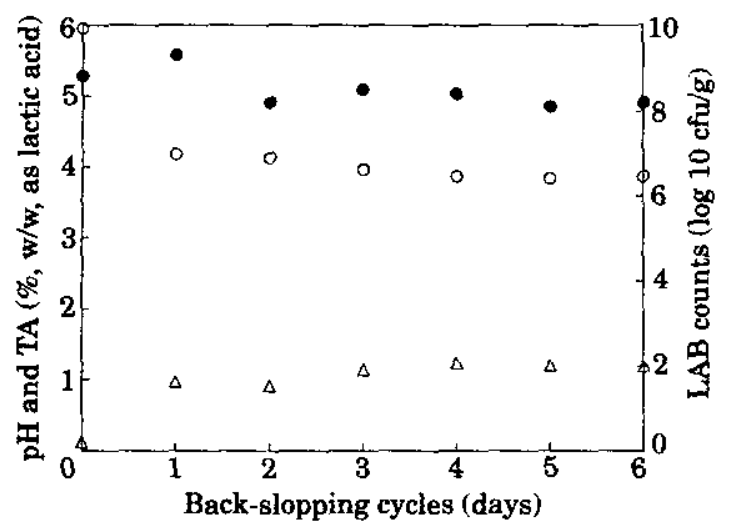

Figure $3 \mathrm{pH}(\mathrm{O})$, titratable acidity $(\Gamma A, \triangle)$ and $\mathrm{LAB}$ population (O) during accelerated natural fermentation with 'back-slopping' of dry-milled maize flour.

Table II Effect of cabinet drying at $60^{\circ} \mathrm{C}$ on the $\mathrm{pH}$ and titratable acidity of kenkey dough

\begin{tabular}{lccc}
$\begin{array}{l}\text { Drying } \\
\text { time }(\mathrm{h})\end{array}$ & $\begin{array}{c}\text { Moisture } \\
\text { content (\%) }\end{array}$ & $\mathrm{pH}$ & $\begin{array}{c}\text { TA (per cent as } \\
\text { lactic acid) }\end{array}$ \\
\hline 0 & 54 & 3.75 & $2 \cdot 87$ \\
1 & 35 & $3 \cdot 75$ & $2 \cdot 58$ \\
2 & 20 & 3.75 & 2.57 \\
3 & 10 & 3.76 & 2.49 \\
\hline
\end{tabular}

${ }^{a} \mathrm{On}$ fresh-weight basis.

b $\mathrm{TA}=$ titratable acidity, expressed on dry-weight basis.

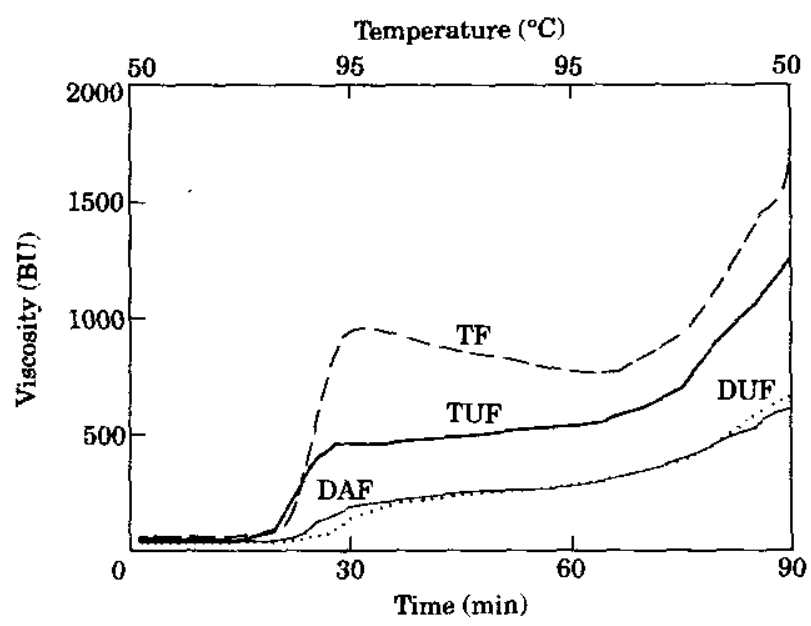

Figure 4 Visco-Amylograms of traditional and dry-milled (accelerated) kenkey flours. TF, traditional fermented dough; TUF, traditional unfermented dough; DAF, dry-milled accelerated (starter) fermented dough; DUF, dry-milled unfermented dough.
Table III Surface colour of dough and kenkey

\begin{tabular}{lrrr}
\hline Sample & \multicolumn{1}{c}{$L$} & \multicolumn{1}{c}{$a$} & \multicolumn{1}{c}{$b$} \\
\hline Traditional dough & $76 \cdot 1 \pm 1 \cdot 2^{a}$ & $-1 \cdot 5 \pm 0 \cdot 7$ & $14 \cdot 4 \pm 0.3$ \\
Traditional kenkey & $63.4 \pm 0.5$ & $1.5 \pm 2 \cdot 4$ & $14 \cdot 0 \pm 1 \cdot 4$ \\
Accelerated dough & $73 \cdot 5 \pm 0.9$ & $-0.8 \pm 0.9$ & $14 \cdot 6 \pm 0.4$ \\
Accelerated kenkey & $63.5 \pm 1.6$ & $0.6 \pm 1 \cdot 3$ & $15 \cdot 1 \pm 0.7$ \\
\hline
\end{tabular}

${ }^{\mathrm{a}}$ Mean \pm s.v.; $n=4$.

Table IV Fracture stress of the different kenkey products

\begin{tabular}{lcc}
\hline Kenkey & $\begin{array}{c}\text { Moisture } \\
\text { content }(\%)\end{array}$ & $\begin{array}{c}\text { Fracture stress } \\
\left(\times 10^{3} \mathrm{~N} / \mathrm{m}^{2}\right)\end{array}$ \\
\hline Traditional & 63.0 & $6.4 \pm 0 \cdot 5^{\mathrm{a}}$ \\
Kenkey A & 67.0 & $4 \cdot 7 \pm 0 \cdot 1$ \\
Kenkey B & 69.0 & $4 \cdot 8 \pm 0.3$ \\
Kenkey C & 68.0 & $3.7 \pm 0.5$ \\
Kenkey D & 60.6 & $5.7 \pm 0.2$ \\
\hline
\end{tabular}

${ }^{a}$ Mean \pm s.D.; $n=4$.

commendable quality. However, minor differences were detected. Type 1 scored better with respect to texture (less sticky) and mildness of taste; whereas type 2 had better scores for uniformity and characteristic kenkey smell and taste.

\section{DISCUSSION}

The results shown in Table I and Fig. 3 confirm earlier reports on naturally fermented cereal doughs ${ }^{3,8}$. As LAB counts increased, more acid was produced, as shown by the increase in titratable acidity (TA) and the decline in $\mathrm{pH}$. Within 3 days of fermentation, the $\mathrm{pH}$ fell to $3 \cdot 96$, well within the inhibitory range for food pathogenic and spoilage bacteria $^{9}$. This drop in $\mathrm{pH}$ is presumed to be responsible for the very low levels of Enterobacteriaceae and yeasts ${ }^{6}$. Other workers attribute this to antibacterial substances such as bacteriocins ${ }^{10}$, organic acids, hydrogen peroxide and antibiotic-like substances ${ }^{6,11}$ produced by the dominant LAB. The rate of acidification was even higher when a starter dough was used, with the $\mathrm{pH}$ dropping from 5.65 to 3.79 within $24 \mathrm{~h}$. This was an indication that inoculum recycling resulted in a natural selection of $\mathrm{LAB}$, which are tolerant to low $\mathrm{pH}$ conditions and can bring about rapid acidification of fresh dough when used as an inoculum ${ }^{6}$. Previous work $^{3}$ has shown that Lactobacillus plantarum and Pediococcus spp. dominate 
the latter stages of maize dough fermentation, and may, therefore, be responsible for the rapid acidification of inoculated dough.

The decrease in TA following drum drying could be due to evaporation of some acid at the higher temperature of the drum $\left(140^{\circ} \mathrm{C}\right)$, which is necessary for proper gelatinisation of the starch component of the dough. Since no cooking was required during cabinet drying, a lower temperature could be used to achieve the required level of dehydration without the loss of acid through evaporation. The fact that dehydration of the fermented maize dough in a cabinet drier did not significantly affect the $\mathrm{pH}$, and titratable acidity is interesting as this portion can then be used to prepare dumplings by mixing with drum-dried aflata. This way the diminished acidity of the drum-dried portion can be compensated for partly by the relatively more sour cabinet-dried portion.

Traditionally fermented dough from soaked maize gave the highest peak viscosity of $950 \mathrm{BU}$ compared with the lower peak viscosity values ( $\leq 300 \mathrm{BU}$ ) of doughs made from dry-milled maize (Fig. 4). This finding is contrary to reports on fermented sorghum flour ${ }^{12}$, but agrees with the report of Banigo et al. ${ }^{13}$, who found that soaking and wet-milling of maize for ogi manufacture increased the swelling and thickening characteristics of the maize starch component.

Damage to starch granules, which may occur during dry milling, can result in increased enzymic hydrolysis of starch up to two-fold ${ }^{14}$, or even sevenfold ${ }^{15}$ in some instances. Thus, fewer intact starch granules undergo swelling and partial solubilisation, especially of amylose. The very low hot and cold paste viscosities of dry-milled flours could, therefore, be the result of mechanical starch damage. Soaking may reduce such damage during milling and thereby result in high viscosities of wet-milled maize doughs; any inhibition of the release of amylose, which may occur due to the binding of lipids and proteins to starch granules, can inhibit gelatinisation and set-back ${ }^{16}$. It has been reported that defatting resulted in the lowering of the gelatinisation temperatures $\left(T_{\mathrm{g}}\right)$ of wheat and maize starches ${ }^{17}$ and in an increase in the pasting viscosity of wheat $\operatorname{starch}^{16}$, although a similar treatment increased the $T_{\mathrm{g}}$ of potato and lentil starches ${ }^{17}$. There is the possibility, therefore, that a lack of proper lipolysis and proteolysis, as might be the case with unsoaked maize grains, might lead to the protein and lipid matrix surrounding the starch granules inhibiting the proper swelling of granules for gelatinisation to occur. It would certainly be interesting to investigate the enzyme activities during soaking and compare this with that in dry-milled grains.

A high set-back viscosity is desirable for proper kenkey quality as this determines the cohesive capacity of the aflata, which serves as a binding agent ${ }^{4}$. If proper gelatinisation is not achieved during the heating phase in the Visco-Amylograph, the set-back viscosity would be low, an indication that any kenkey from such a dough will be crumbly and friable.

During the drum-drying of soaked maize dough, a complete breakdown of the starch granule structure $^{18}$ occurs, and hence rapid gelatinisation and solubilisation of released starch. Poor release of amylose from dry-milled flours would, however, result in less gelatinisation and subsequently a lower set-back potential during drum drying. Rehydration $(3: 1 ; \mathrm{v} / \mathrm{w})$ of the drum-dried flour yielded a smooth and gluey aflata, which was easier to handle than the hot paste obtained from the traditional aflata process. The low degree of setback in drum-dried, dry-milled unfermented maize flour is reflected in the inferior fracture stress values for kenkey $\mathrm{C}$, produced from this flour (Table IV). In fact, kenkey $\mathrm{C}$ was a crumbly and friable product that fell apart quite easily. The slightly lower fracture stress values of kenkeys A and $\mathrm{B}$, compared with traditional kenkey, could be accounted for by the higher moisture contents of these kenkeys. Kenkeys A and B were less brittle, however, reflecting the higher degree of starch gelatinisation and subsequent set-back (Fig. 4, see TF and TUF). This is a desirable characteristic of kenkey, and can be obtained only in the traditional process if small quantities of kenkey are made at any one time. To obtain such a quality for larger quantities of kenkey would be laborious and time consuming. Bediako-Amoa and Austin ${ }^{19}$ also observed that satisfactory aflata could be produced from pre-gelatinised starch to avoid the strenuous physical work involved in the traditional process.

For logistic reasons, kenkey samples 1 and 2 were made from different batches of maize, and their fermentation was carried out under different conditions (i.e. in the laboratory in The Netherlands, and in the traditional artisan fashion in Ghana). These factors will certainly have contributed to the observed difference in smell and taste. For the purpose of the present research, however, the textural behaviour was of major importance, since it could be affected strongly by 
pre-cooking, dehydration and reconstitution. The positive response in relation to the texture of kenkey 1 [Fig. 1 (a)] is encouraging indeed and indicates that the concept of an 'intermediate kenkey dry mix' has good chances of consumer acceptance.

The findings in this paper indicate clearly that, although accelerated acidification of dry-milled rnaize flour can be achieved by using a starter dough, proper gelatinisation is necessary during the aflata process in order to obtain the desired physical characteristics of kenkey. The rejection of kenkeys $\mathrm{C}$ and $\mathrm{D}$ by the laboratory-scale screening panel was a confirmation of the physical evidence showing inferior pasting properties of dough from dry-milled maize, compared with dough from wetmilled maize. Pre-gelatinisation offers an alternative way of aflata production with minimum physical labour on condition that the treatment of dough prior to gelatinisation is optimised with regard to maximum swelling and set-back.

\section{Acknowledgement}

This work was carried out in the context of an E.C.sponsored project (contract no. TS2-0267-UK; 'The evaluation and improvement of traditional fermented cereals and legumes in Ghana'). The collaboration of Unilever Research Laboratory, Vlaardingen, The Netherlands is gratefully acknowledged.

\section{REFERENCES}

1. Muller, H.G. Traditional cereal processing in Nigeria and Ghana. Ghana Journal of Agriculture and Science 3 (1970) $187-191$.

2. Muller, H.G. and Nyarko-Mensah, B. Studies on kenkey, a Ghanaian cereal food. Journal of the Science of Food and Agriculture 23 (1972) 544-545.

3. Nche, P.F., Nout, M.J.R. and Rombouts, F.M. The effect of cowpea-supplementation on the quality of kenkey, a traditional Ghanaian fermented maize food. Journal of Cereal Science 19 (1994) 191-197.

4. Sefa-Dedeh, S. and Plange, H. Processing of Ga kenkey
(Komi) in Greater Accra region. A techno-economic study. Kellogg International Report no. 03/1988 (1989) 1-36.

5. Nout, M.J.R., Beernink, G. and Bonants-Van Laarhoven, T.M.G. Growth of Bacillus cereus in soya bean tempeh. International Journal of Food Microbiology 4 (1987) 293-301.

6. Nout, M.J.R., Rombouts, F.M. and Havelaar, A. Effect of accelerated natural lactic fermentation of infant food ingredients on some pathogenic microorganisms. International Journal of Food Microbiology 8 (1989) 351-361.

7. Van Vliet, T. Rheological and fracture properties of cheese. Bulletin of the Intemational Dainy Federation 268 (1991) $17-23$.

8. Chavan, V.D., Chavan, J.K. and Kadam, S.S. Effect of fermentation on soluble proteins and in vitro protein digestibility of sorghum, green gram and sorghum-green gram blends. Fournal of Food Science 53 (1988) 1574-1575.

9. Hamad, A.M. and Fields, M.L. Evaluation of the protein quality and available lysine of germinated and fermented cereals. Fournal of Food Science 44 (1979) 456-459.

10. Mensah, P., Tomkins, A.M., Drasar, B.S. and Harrison, T.J. Antimicrobial effect of fermented Ghanaian maize dough. Journal of Applied Bacteriology 70 (1991) 203-210.

11. Gibbs, P.A. Novel uses for lactic acid fermentation in food preservation. Journal of Applied Bacteriology, Symposium Supplement 16 (1987) S5l-S58.

12. Adeyemi, I.A. Dry-milling of sorghum for ogi manufacture. Journal of Cereal Science 1 (1983) 221-227.

13. Banigo, E.O.I., De Man, J.M. and Duitschaever, C.L. Utilization of high lysine corn for fermentation of ogi using a new and improved processing system. Cereal Chemisiry 51 (1974) 559-572.

14. Schweizer, T.F., Reimann, S. and Würsch, P. Definition and measurement of starch digestion index and the study of factors determining starch digestion rates in foods. Lebensmittel Wissenschaft und Technologie 21 (1988) 352-357.

15. Wong, S. and Trianedes, K. Factors affecting the rate of starch digestion in legumes. American Joumal of Clinical Nutrition 42 (1985) 38-43.

16. Eliasson, A.C., Carlson, T.L.G., Larsson, K. and Miezis, Y. Some effects of starch lipids on the thermal and rheological properties of wheat starch. Starch/Stärke 33 (1981) 130-134.

17. Vasanthan, T. and Hover, R. Effect of defatting on starch structure and physicochemical properties. Food Chemistry 45 (1992) 337-347.

18. Bean, M.M. and Setser, C.S. Polysaccharides, sugars and sweeteners. In 'Food Theory and Applications', 2nd edn. (J. Bowers, ed.) Macmillan, New York (1992) pp 69-198.

19. Bediako-Amoa, B. and Austin, F.A. Investigation of the aflata process in kenkey manufacture. Ghana Journal of Agrioulture and Science 9 (1976) 59-61. 